\title{
Can Europe recover without credit? ${ }^{1}$
}

\author{
Zsolt Darvas \\ Associate Professor, Corvinus University of Budapest, Department of Mathematical \\ Economics and Economic Analysis \\ Research Fellow, Bruegel \\ Research Fellow, Research Centre for Economic and Regional Studies of the Hungarian \\ Academy of Sciences. \\ E-mail: zsolt.darvas@uni-corvinus.hu
}

Data from 135 countries covering five decades suggests that creditless recoveries, in which the stock of real credit does not return to the pre-crisis level for three years after the GDP trough, are not rare and are characterised by remarkable real GDP growth rates: 4.7 percent per year in middle-income countries and 3.2 percent per year in high-income countries. However, the implications of these historical episodes for the current European situation are limited, for two main reasons. First, creditless recoveries are much less common in highincome countries, than in low-income countries which are financially undeveloped. European economies heavily depend on bank loans and research suggests that loan supply played a major role in the recent weak credit performance of Europe. There are reasons to believe that, despite various efforts, normal lending has not yet been restored. Limited loan supply could be disruptive for the European economic recovery and there has been only a minor substitution of bank loans with debt securities. Second, creditless recoveries were associated with significant real exchange rate depreciation, which has hardly occurred so far in most of Europe. This stylised fact suggests that it might be difficult to re-establish economic growth in the absence of sizeable real exchange rate depreciation, if credit growth does not return.

Keywords: creditless recovery, credit growth financial structure, real exchange rate adjustment

JEL-codes: E32, E44, E51, F31, G21, O46

\footnotetext{
${ }^{1}$ Thanks are due to Hannah Lichtenberg and Li Savelin for research assistance, and to Bruegel colleagues for comments. The first version of this paper was prepared as a background paper for Indermit Gill, Martin Raiser and others (2012) 'Golden growth: Restoring the lustre of European economic model', Washington DC: World Bank.
} 


\section{Introduction}

Access to finance of corporations is a crucial prerequisite for growth. Beyond using existing cash balances, retaining profits and raising new equity, options that are typically limited during a recession. Borrowing can provide funds for day-to-day financial operations and long-term investment.

In continental Europe, borrowing from banks is the dominant source of debt financing for non-financial corporations, and there has been little change in this during the past decade (Figure 1). In contrast, the share of debt securities is much higher in the United States and the issuance of debt securities overcompensated for the drop in bank credit from 2008 to $2013 .{ }^{2}$ Developments in the United Kingdom are in between the euro area and the US in these regards, while in other EU countries, bank loans tend to dominate even more than in the euro area.

Figure 1. Debt liabilities of non-financial corporations, 1999Q1-2013Q2

A. Euro area (€ billions) $\quad$ B. United Kingdom (£ billions) C: United States ( $\$$ billions)

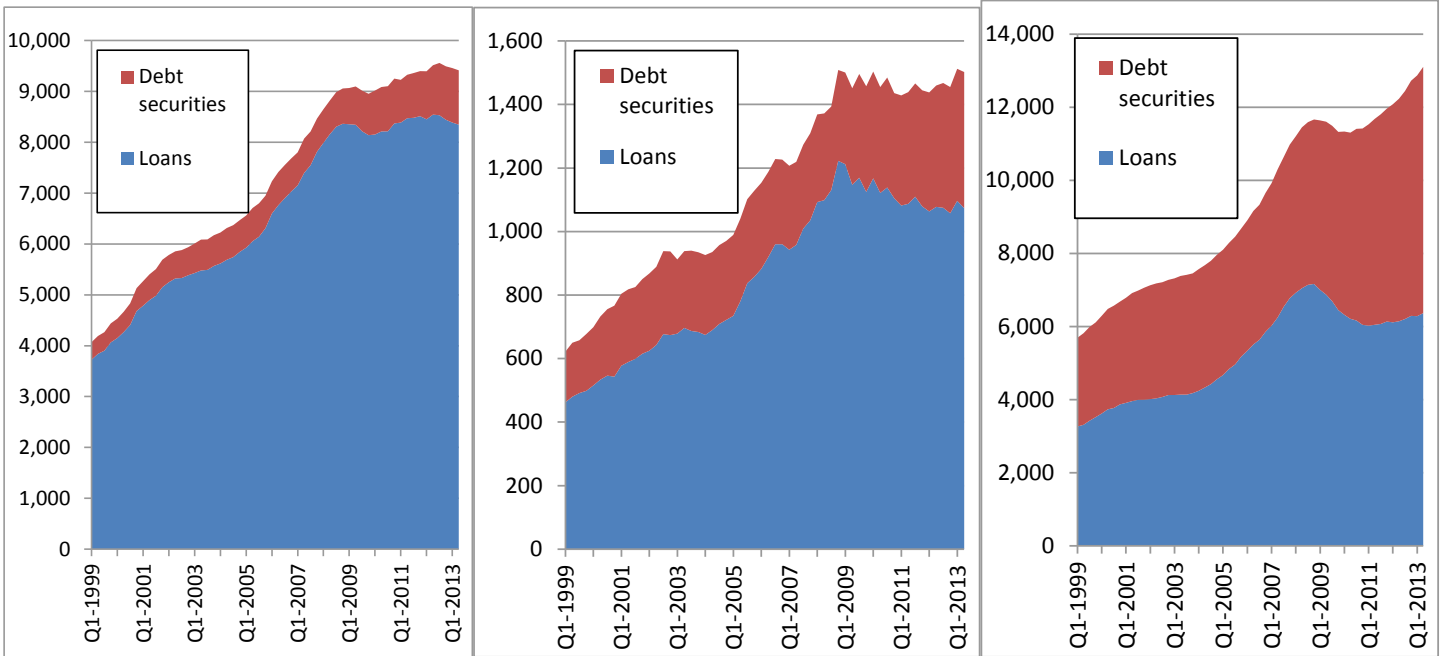

Source: author's calculations based on OECD 'Non-consolidated financial balance sheets by economic sector'. Note: quarterly balance sheet data. Debt securities correspond to 'Securities other than shares, excluding financial derivatives'.

Credit growth has not yet resumed in most European countries, and credit is even declining in nominal terms in a number of countries. The declines in real terms are more significant. Clearly, economic growth and credit growth are simultaneous and it is not just that credit can drive the economy, but the reverse causality also exists. Economic growth can increase both credit demand (households and corporations are more willing to consume and invest when the economic outlook improves) and credit supply (economic growth improves bank balance sheets and thereby their ability to supply credit). But credit market conditions can also amplify shocks to the economy, as suggested for example by the financial accelerator theory (Bernanke et al. 1996).

There is abundant academic research concluding that limitations in credit supply have played a major role in credit developments recently, as we will summarise in this article. Such supply constraints could hinder credit expansion even if higher credit demand returns. Given

\footnotetext{
${ }^{2}$ Since the debt securities market is accessible for large firms only, total debt liabilities of small and mediumsized enterprises (SMEs) might not have increased, even in the US.
} 
the prominent role of credit in the European economy and the limited substitution of bank loans with debt securities, one should be concerned about the consequences for economic growth.

However, while economic theory predicts a close association between credit supply and the business cycle (Abiad et al. 2011), recent empirical literature has pointed out that there were a number of economic recoveries without credit growth, which are called 'creditless recoveries'. Calvo et al. (2006a; b) were among the first to observe this phenomenon by studying a sample of emerging market economies after systemic sudden stops. They dubbed such developments 'Phoenix miracles' and showed that such recoveries are common, even though investment, a key driver of growth in normal times, remains weak in creditless recoveries.

Subsequent research, such as Claesens et al. (2009a; b), International Monetary Fund (2009), Abiad et al. (2011), Bijsterbosch and Dahlhaus (2011), and Coricelli and Roland (2011), has looked at various other aspects of creditless (and also with-credit) recoveries. These studies have concluded that creditless recoveries are not rare events (they account for about every fifth recovery), but growth is about a third lower (i.e. 4.5 percent per year on average during the first three years of the recovery, as calculated by Abiad et al. 2011) than in recoveries with credit (when average growth was found to be 6.3 percent per year). Creditless recoveries are typically preceded by banking crises and sizeable output falls. Industries that are more reliant on external finance grow disproportionately less during creditless recoveries. Several papers also conclude that impaired financial intermediation and limited credit supply are the major reasons behind sluggish credit growth during creditless recoveries.

Given this cautiously optimistic literature on the existence of creditless recoveries, it is relevant to ask if European economies could also expect to grow without credit in the coming years. This question also has a bearing on three current policy debates. One is the ongoing development of the European Banking Union, which, among others, aims to foster better access to finance. Another one is the development of specific instruments (beyond the banking union) to foster access to finance in the EU, and in particular to small and mediumsized enterprises (SMEs). And a third related policy debate is on the targets and implementation speed of the Basel III requirements, since new capital, liquidity and leverage rules will likely impact on the ability of banks to supply credit to the economy.

The goal of this article is to shed light on some less researched aspects of creditless recoveries: the role of exchange rate changes and financial development. After establishing some stylised facts using a sample of 135 countries and almost five decades of data, we assess the potential for creditless recoveries in Europe.

\section{Creditless recoveries in a historical perspective: a new look}

In our view, real exchange rate developments could play a major role in understanding creditless recoveries, yet the literature has not paid sufficient attention to this issue. While dummy variables indicating the existence of a currency crisis were included in some papers, this indicator does not capture the magnitude and persistence of exchange rate changes. In addition, exchange rates also changed in those cases that are not classified as currency crises.

For example, Figure 2 shows that all four 'true miracles' identified by Abiad et al. (2011), i.e. 
cases with exceptional high economic growth without cumulative real credit growth three years after the trough, were characterised by very large falls in the real exchange rate close to the GDP trough.

Figure 2. Examples of credit-less recoveries, the four 'true miracles' (year of trough $=100$ )
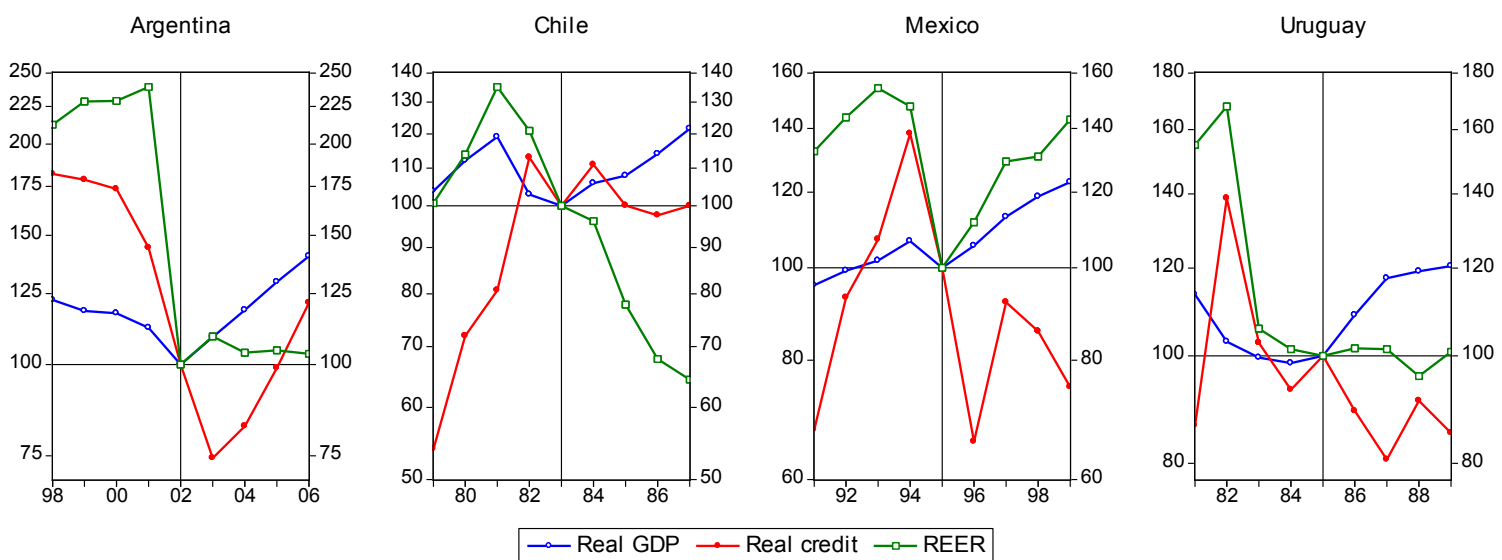

Sources: author's calculations using data listed in the data appendix. Note: real credit is credit to the private sector deflated using the consumer price index. REER = real effective exchange rate, which was calculated against 145 trading partners for Argentina, Mexico and Uruguay and against 99 trading partners for Chile using trade weights and consumer prices.

In addition to bringing the real exchange rate into the analysis, we also include trade openness and financial development. Trade openness may have a bearing on the impact of the exchange rate on the economy, while financial development may directly impact the incidence of creditless recoveries. For example, economies in their financial infancy might not be much impacted by the availability or the lack of credit, but credit constraints could be disruptive when companies rely heavily on credit. ${ }^{3}$

\section{Sample}

Our sample includes annual data from 1960 for 135 countries for which data on output, credit and real effective exchange rate (REER) are available. ${ }^{4}$ We have excluded the period of the recent global crisis from the sample to search for recoveries (i.e. do not consider troughs during 2007-2012), but we use GDP data up to 2017 from the October 2012 forecast of the IMF in order to reduce the end-of-sample problem of the Hodrick-Prescott filter. ${ }^{5}$ We have excluded transition countries (up to the mid-1990s) and Middle Eastern oil exporting countries, since the transition was characterised by enormous structural changes and the economies of oil exporters substantially differ from the economies of EU countries.

\section{Definitions of business cycle trough and creditless recoveries}

Similarly to Braun and Larrain (2005), Abiad et al. (2011) and Bijsterbosch and Dahlhaus (2011), we define the trough of the business cycle as the lowest point of the cyclical

\footnotetext{
${ }^{3}$ Abiad et al. (2011) mention, incidentally, that creditless recoveries are more common in countries with less developed financial markets.

${ }^{4}$ We have checked 178 countries and the main bottleneck was the availability of credit data.

${ }^{5}$ The filter developed by Hodrick and Prescott (1997) is a statistical method for decomposing a time series into trend and cyclical components. It is based on the assumption that the trend component is smooth and the smoothness can be set by altering a parameter. One problem with the filter is end-of-sample instability: when new observations are added, the estimated trend and cyclical components for the last few observations of the previous sample can change significantly.
} 
component of real GDP identified by the Hodrick-Prescott filter with smoothing parameter 6.25, which is the suggestion of Ravn and Uhlig (2002) for annual data. We only consider those troughs for which the lowest point of the cyclical component is below zero by more than its standard deviation. The recovery period is defined as the first three years following the trough. We required at least four years between subsequent troughs. The recovery is defined as 'creditless' when the level of real credit stock (claims on private sector, IFS line $32 \mathrm{D}^{6}$, deflated with the consumer price index) for three years after the trough is lower than in the year of trough. ${ }^{7}$

\section{The two main tables}

Table 1 shows some main characteristics of both creditless and with-credit recoveries. We report median values of the various indicators, because there are a number of outliers in our sample. Table 2 reports test statistics checking the significance of the difference between the median values of the indicators for creditless and with-credit recoveries. In addition to total, we report statistics for three income groups based on GDP per capita relative to the US in the trough year: below 10 percent, between 10 and 60 percent, and above 60 percent and hereafter call these groups low-income, middle-income and high-income, respectively. Currently, EU countries would belong to the middle- and high-income groups and therefore we focus on these groups. ${ }^{8}$

Table 1. Some key characteristics of creditless and with-credit recoveries

\begin{tabular}{|c|c|c|c|c|c|}
\hline & \multirow[b]{2}{*}{$\begin{array}{l}\text { Type of } \\
\text { recovery }\end{array}$} & \multicolumn{4}{|c|}{ Per capita income (\% US) } \\
\hline & & $\begin{array}{c}\text { below } \\
10 \%\end{array}$ & $\begin{array}{c}\text { between } \\
10 \% \text { and } \\
60 \%\end{array}$ & $\begin{array}{c}\text { above } \\
60 \%\end{array}$ & All \\
\hline \multirow{3}{*}{ Number of recoveries } & creditless & 38 & 32 & 12 & 82 \\
\hline & with credit & 112 & 152 & 82 & 346 \\
\hline & $\%$ creditless & $25.3 \%$ & $17.4 \%$ & $12.8 \%$ & $19.2 \%$ \\
\hline \multirow{2}{*}{$\begin{array}{l}\text { Median real GDP growth (average of three years after } \\
\text { trough) }\end{array}$} & creditless & 4.8 & 4.7 & 3.2 & 4.5 \\
\hline & with credit & 6.4 & 6.8 & 4.1 & 6.0 \\
\hline \multirow{2}{*}{$\begin{array}{l}\text { Median real GDP growth of trading partners (average of } \\
\text { three years after trough) }\end{array}$} & credi-less & 3.5 & 3.6 & 3.5 & 3.5 \\
\hline & with credit & 3.7 & 3.8 & 4.0 & 3.8 \\
\hline \multirow{2}{*}{$\begin{array}{l}\text { Median real GDP growth relative to growth of trading } \\
\text { partners (average of three years after trough) }\end{array}$} & creditless & 1.2 & 1.2 & -0.5 & 0.8 \\
\hline & with credit & 2.7 & 2.7 & -0.1 & 1.9 \\
\hline \multirow{2}{*}{ Median credit (\% GDP) } & creditless & 15 & 30 & 50 & 27 \\
\hline & with credit & 15 & 30 & 52 & 26 \\
\hline \multirow{2}{*}{ Median current account adjustment (\%GDP) } & credit-less & 8.0 & 8.6 & 6.5 & 8.0 \\
\hline & with credit & 5.5 & 5.7 & 3.0 & 4.6 \\
\hline Median REER in 3 years after trough (\%pre-trough & credit-less & 93 & 76 & 90 & 86 \\
\hline
\end{tabular}

\footnotetext{
${ }^{6}$ As emphasised by Abiad et al. (2011), the IFS credit data has shortcomings: it does not include credit extended by non-bank financial intermediaries, and also does not include borrowing from abroad. But this is the only source with sufficient time and country coverage.

${ }^{7}$ Note that the Argentine and the Chilean episodes shown in Figure 2 just marginally pass this criterion.

${ }^{8}$ The level of a country's development has a major bearing on growth drivers, see e.g. Veugelers (2011), justifying the focus on high- and middle-income countries when we wish to draw lessons for EU countries. Considering GDP per capita at PPP in 2013, as projected by the IMF October 2012 World Economic Outlook, Italy, Greece, Spain and Portugal and all thirteen member states that joined the EU in 2004 and 2013 would belong to the middle income middle-group. The other eleven EU member states would be in the high-income group.
} 


\begin{tabular}{llllll} 
peak) & with credit & 91 & 93 & 98 & $\mathbf{9 4}$ \\
\hline \multirow{2}{*}{ Median openness (exports+imports, \%GDP) } & credit-less & 52 & 56 & 61 & $\mathbf{5 6}$ \\
& with credit & 54 & 80 & 62 & $\mathbf{6 3}$ \\
\hline
\end{tabular}

Source: author's calculations.

Table 2. Wilcoxon-Mann-Whitney test for the equality of medians between the indicators creditless and with-credit recoveries

\begin{tabular}{|c|c|c|}
\hline & Full sample & $\begin{array}{l}\text { Excluding low } \\
\text { income countries }\end{array}$ \\
\hline Median real GDP growth (average of three years after trough) & $\begin{array}{c}4.21 \\
(0.000)\end{array}$ & $\begin{array}{c}3.21 \\
(0.001)\end{array}$ \\
\hline $\begin{array}{l}\text { Median real GDP growth of trading partners (average of three } \\
\text { years after trough) }\end{array}$ & $\begin{array}{c}2.78 \\
(0.006)\end{array}$ & $\begin{array}{c}2.20 \\
(0.028)\end{array}$ \\
\hline $\begin{array}{l}\text { Median real GDP growth relative to growth of trading } \\
\text { partners (average of three years after trough) }\end{array}$ & $\begin{array}{c}2.95 \\
(0.003)\end{array}$ & $\begin{array}{c}2.01 \\
(0.044)\end{array}$ \\
\hline Median credit (GDP \%) & $\begin{array}{c}0.49 \\
(0.613)\end{array}$ & $\begin{array}{c}0.28 \\
(0.777)\end{array}$ \\
\hline Median current account adjustment (\%GDP) & $\begin{array}{c}4.03 \\
(0.000)\end{array}$ & $\begin{array}{c}3.75 \\
(0.000)\end{array}$ \\
\hline Median REER in 3 years after trough (\%pre-trough peak) & $\begin{array}{c}2.18 \\
(0.029)\end{array}$ & $\begin{array}{c}2.80 \\
(0.005)\end{array}$ \\
\hline Median openness (exports+imports, \%GDP) & $\begin{array}{c}1.18 \\
(0.240)\end{array}$ & $\begin{array}{c}1.18 \\
(0.239)\end{array}$ \\
\hline
\end{tabular}

Source: author's calculations. Notes: p-values are in parentheses. Test statistics significant at 5 percent level are in italics. The Wilcoxon-Mann-Whitney test is a non-parametric statistical hypothesis test.

\section{Incidence of creditless recoveries}

There are 428 recoveries in our sample of which 82 are creditless, i.e. about every fifth recovery. The incidence of creditless recoveries is highest in low-income countries (25.3 percent) and lowest in high-income countries (12.8 percent). ${ }^{9}$ In high-income countries, there were only 12 cases of creditless recoveries, the most recent in 1993, as indicated in Appendix $2 .^{10}$

\section{Growth}

Table 1 confirms the results from the literature that economic growth tends to be remarkable during the first three years of creditless recoveries (4.5 percent per year averaged across the full sample), even though it is less rapid than in recoveries with credit (6.0 percent). In highincome countries, the median speed of economic growth during the first three years of creditless recoveries is also impressive, 3.2 percent per year, just below the 4.1 percent

\footnotetext{
${ }^{9}$ These results are consistent with the findings of Abiad et al. (2011), who analyse 362 recoveries.

${ }^{10}$ Note that we classify countries according to GDP per capita at PPP relative to the US in the year of trough, and therefore the twelve high-income countries with creditless recoveries also include the Bahamas in 1975 and Gabon in 1978 (see Appendix 2).
} 
annual growth rate during recoveries with credit.

Yet the GDP growth rate may not be the best indicator for assessing the speed of recovery, because the global growth environment likely has an impact. Table 1 shows that GDP growth of trading partners used to be somewhat faster in recoveries with credit, though the difference is not large. Growth relative to trading partners was 2.7 percent during with-credit recoveries in low- and middle-income countries, and 1.2 percent during creditless recoveries, which is still quite substantial. In high-income countries, the difference between growth relative to trading partners of the two types of recoveries is smaller.

\section{Financial development}

We measured financial development using the credit/GDP ratio, which is an imperfect measure, but the only one available for a large number of countries across several decades. The median of this indicator is practically identical for creditless and with-credit recoveries, and therefore within an income group, financial development does not seem to make a difference for the incidence of creditless recoveries. However, Table 1 also confirms that economic and financial developments correlate positively and we have already found that the incidence of creditless recoveries declines with the level of economic development. Therefore, we can also conclude that creditless recoveries are rare at a higher level of financial development, which is confirmed by Figure 3.

Figure 3. Histogram of the credit/GDP ratios of the 82 creditless recoveries

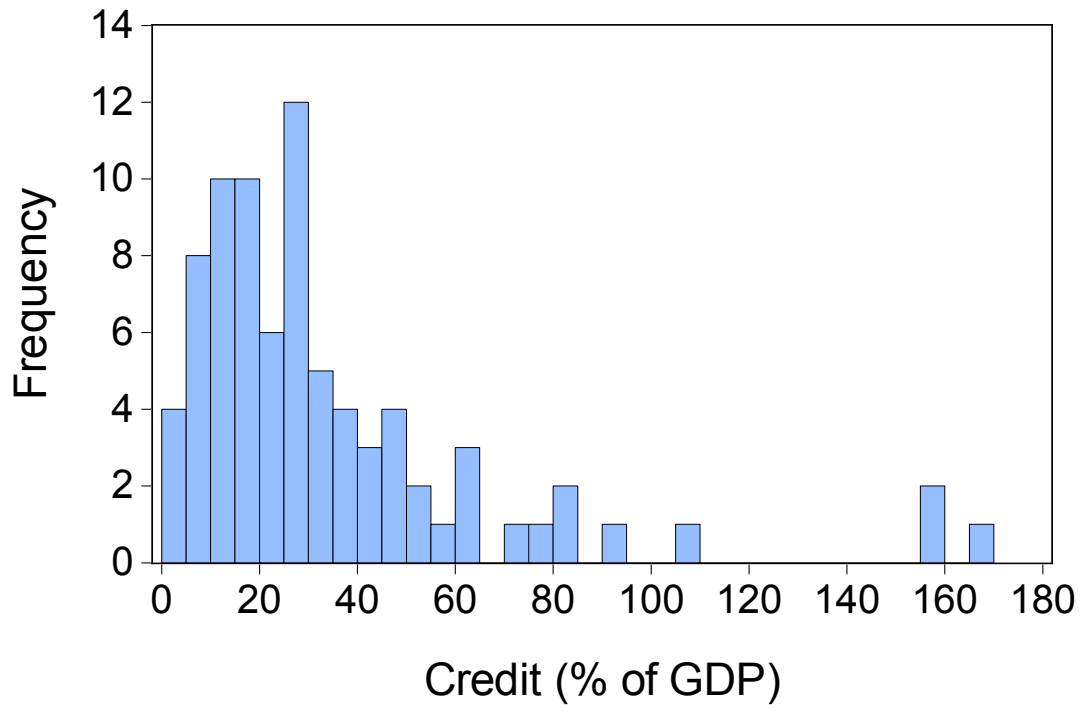

Source: author's calculations.

Note: the four cases with more than 100 percent of GDP credit stock are Hong Kong in 1989 (169 percent), Malaysia in 1998 (156 percent), Thailand in 1998 (156 percent) and in Portugal 1975 (106 percent). In these cases the depreciation of the real exchange rate in three years after the trough compared to the pre-crisis peak was 8 percent, 16 percent, 58 percent and 18 percent, respectively.

\section{Current account}

Next, Table 1 indicates the magnitude of current account adjustment, which is defined as the difference between the maximum of current account/GDP positions during the three years after the trough, minus the minimum during the three years before the trough. Creditless recoveries are associated with greater current account adjustment, by about 3 percentage points of GDP, in all three income groups. 


\section{Real exchange rate}

Current account adjustments are facilitated by adjustment in the real exchange rate. Table 1 shows that all recoveries in all three income groups tended to be associated with lasting real effective exchange rate depreciations, and depreciations tended to be greater in creditless recoveries compared to with-credit recoveries, except in low-income countries. The difference in median cases of creditless and with-credit recoveries is significant (Table 2). In the middle-income countries, the median real effective depreciation is 24 percent from the pre-trough peak until three years after the trough in the creditless cases, and only seven percent in the with-credit cases. The same figures for high-income countries are 10 percent and two percent. And in several cases, part of the depreciation was corrected by the third year after the trough and therefore the maximum depreciation was even larger.

However, while creditless recoveries tend to be accompanied by sizeable and durable real exchange rate depreciations, this is not always the case. Figure 4 indicates that the median real exchange rate clearly tends downward during creditless recoveries in middle-income countries, but the upper boundary of the interquartile range remains close to 100, implying that there was no depreciation in about every fourth creditless recovery. Among the highincome countries, in two of the 12 cases the real exchange rate was at a higher level three years after the trough than the maximum before the trough.

Figure 4. REER developments during creditless recoveries in middle- and high-income countries (pre-trough peak in REER $=100$ )

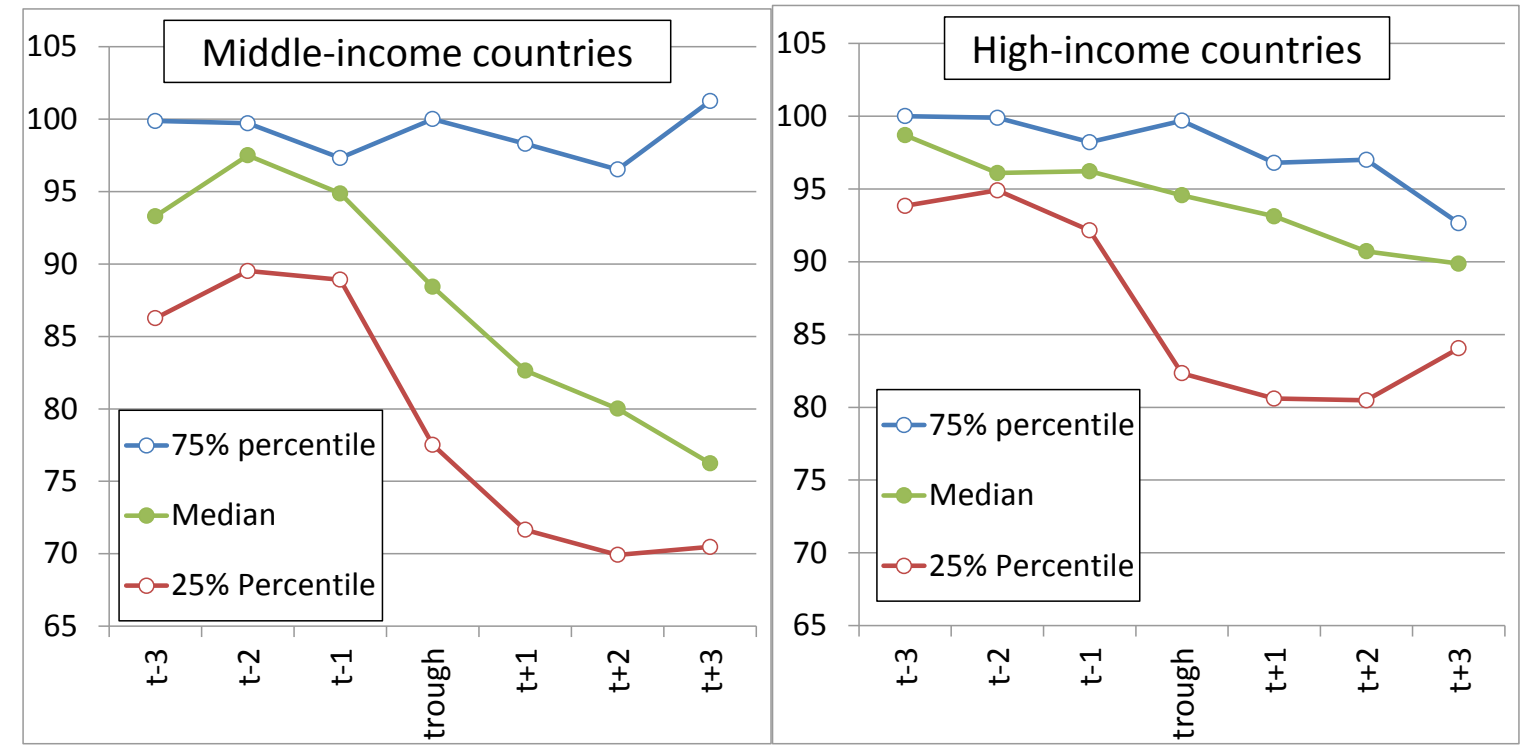

Source: Author's calculations.

Note. The pre-trough peak in real effective exchange rates occurred in different years (see also e.g. Figure 2: in trough minus one year in Argentina, in trough minus two years in Chile and Mexico, and in trough minus three years in Uruguay), and therefore the median is not equal 100 in any particular year before trough. The 75 percent and the 25 percent refer to the first and third quartiles of the distribution of the REER developments (i.e. denote the boundaries of the interquartile range).

Consequently, not all, but most, creditless recoveries are associated with sizeable and durable real exchange rate depreciations, and the median depreciation is significantly larger than the depreciation during recoveries with credit in middle- and high-income countries.

Trade openness 
Finally, we also checked if creditless recoveries emerged in countries more open to international trade, but this is not the case. If anything, countries with with-credit recoveries are somewhat more open (Table 1), but the difference is not significant (Table 2).

\section{Understanding creditless recoveries}

As Abiad et al. (2011) rightly argue, creditless recoveries are puzzling from a theoretical perspective. While Calvo et al. (2006a), and Biggs et al. (2009) sketch brief analytical models, it is fair to claim that comprehensive theoretical models have not been developed to understand creditless recoveries. Instead, authors studying such recoveries put forward certain hypotheses to explain them, as follows:

- Absorption of idle capacities: creditless recoveries used to happen after deep recessions and thereby idle capacities are available for growth: firms could exploit these capacities without investing (e.g. Calvo et al. 2006a; b; Abiad et al. 2011; and Coricelli - Roland, $2011) ;^{11}$

- Role of liquidity: following a liquidity crunch, liquidity is restored by discontinuing investment projects, meaning that firms do not borrow (eg Calvo et al. 2006a; b);

- Incorrect measurement of credit developments: the change in credit growth may matter more for output growth than credit growth itself. When, for example, credit falls sharply in the trough year, but credit growth stabilises in the next year (even if at a negative growth rate), then the change in credit growth is positive in the year after the trough, and that may help economic recovery (Biggs et al. 2009);

- Alternative financing: firms can rely on alternative sources of financing, such as trade credit (e.g. Claessens et al., 2009; Coricelli - Roland, 2011);

- Reallocation: a reallocation from more to less credit-intensive sectors takes place (e.g. Claessens et al., 2009; Abiad et al. 2011; Coricelli - Roland, 2011);

- Strong external demand: disruptions to the supply of credit may not matter much for firms that are highly dependent on outside funding, if they produce goods that are highly tradable (IMF 2009).

These explanations could all be valid to some extent, except perhaps the last one, because, as we found in Tables 1 and 2, GDP growth of trading partners tended to be faster in recoveries with credit. But our preceding analysis underlined that one more factor has to be added:

- Real exchange rate depreciation: can help finance exporting firms via increased trade revenues.

We cannot claim causality - that the weak real exchange rate causes output to recover when credit does not expand - because GDP growth, credit growth and the real exchange rate are endogenous variables and we do not have a well identified formal model to back us up. Yet the stylised fact we established suggests that economic growth may prove to be difficult in the absence of sizeable real exchange rate depreciation, if credit growth does not return.

\section{Implications for Europe}

\footnotetext{
11 The results of the probit model estimates of Bijsterbosch and Dahlhaus (2011) are consistent with this interpretation, since they find that among the statistically significant variables linked to the incidence of creditless recoveries, two variables, the preceding output fall and the occurrence of a banking crises, are economically significant.
} 
Before the crisis, there was probably too much bank credit in several European countries. But the stock of bank loans (in nominal terms) at the end of 2012 was either similar to the 2008 stock or even lower in all countries and areas indicated in Table 3. The only notable nominal increase can be observed in the seven Central and Eastern European countries outside the euro area (CEE7). But this is largely due to the revaluation effect of foreign currency loans, because currency exchange rates depreciated in Hungary, Poland and Romania, where foreign currency loans were widespread. In real terms, there was a fall in all areas and countries indicated in the table.

Table 3: Loans to non-financial corporations measured in domestic currency $(2008=100)$

\begin{tabular}{llccc}
\hline & & 2000 & 2008 & 2012 \\
\hline Euro area 17 & nominal & 55 & 100 & 99 \\
United Kingdom & real & 66 & 100 & 91 \\
& nominal & 48 & 100 & 89 \\
Denmark & real & 56 & 100 & 78 \\
& nominal & 48 & 100 & 94 \\
Sweden & real & 56 & 100 & 86 \\
& nominal & 46 & 100 & 100 \\
CEE 7 & real & 53 & 100 & 94 \\
& nominal & 33 & 100 & 110 \\
& real & 45 & 100 & 95
\end{tabular}

Source: author's calculations using data from the 'Financial balance sheets' and 'Harmonised indices of consumer prices' databases of Eurostat.

Note: CEE7 is the aggregate of the seven countries in Central and Eastern Europe that are not members of the euro area: Bulgaria, Czech Republic, Hungary, Latvia, Lithuania, Poland and Romania. Consolidated data is used.

Two major issues have to be discussed for the assessment of the potential for creditless recoveries in Europe: the role of supply and demand in credit contraction, and the potential for alternative source of financing beyond bank loans.

\section{Credit supply and demand}

The fall in credit aggregates could be related to both credit supply and credit demand, but also the writing-down of loans:

- Credit supply: banks facing a deteriorating loan portfolio during a recession can tighten credit standards and reduce credit supply. New requirements for higher capital and liquidity ratios and lower leverage can also lead to a reduction of credit.

- Credit demand: with the fall in output and increased uncertainty about the outlook, firms reduce their production and investment activities, and thereby reducing credit demand. Also, highly indebted firms may wish to deleverage during a downturn.

- Write-downs: in a recession bankruptcies increase and banks suffer losses on their loan portfolios and write-down some claims, which also reduces the aggregate stock of loans.

All three factors can play a role during creditless recoveries and from a policy perspective they have different implications. However, several research papers suggest that credit supply had a major role, both during earlier creditless recovery episodes and during the current 
episode of sluggish credit development.

Regarding earlier episodes, it was found that industries that are more dependent on external finance are hit harder during recessions (a finding corroborated by Braun - Larrain 2005) and these industries recover disproportionately less during a creditless recovery than those that are more self-financed (a finding of Abiad et al. 2011). When bank loans, debt securities and equity are not perfect substitutes, these findings suggest that impaired financial intermediation, and hence limitations in credit supply, was a major reason for past creditless recoveries.

There is also abundant academic research concluding that recently, limited credit supply was an important factor in credit developments in several advanced economies. Hampell and Sorensen (2010) adopt a panel-econometric approach applied to a unique confidential dataset of results from the Eurosystem's bank lending survey, and conclude that even after controlling for various demand-side factors, loan growth is negatively affected by supply-side constraints. Using a different technique - panel vector autoregression identified with sign restrictions - Hristov et al. (2012) find that that loan-supply shocks significantly contributed to the evolution of the loan volume and real GDP growth in euro-area member countries during the financial crisis. The role of credit supply is also corroborated by country-specific studies, for example for Italy by Del Giovane et al. (2012) and for Spain by Jiménez et al. (2012).

Empirical results for non-euro area countries are similar. Aiyar (2011) looked at UK banks using detailed confidential balance sheet data reported to the Bank of England, and found that shocks to foreign funding caused a substantial pullback in domestic lending.

Using US firm-level data, Becker and Ivashina (2011) interpret switching by firms from loans to bonds as a contraction in credit supply, conditional on the issuance of new debt. They find strong evidence of substitution of loans by bonds during periods characterised by tight lending standards, high levels of non-performing loans and loan allowances, low bank share prices and tight monetary policy. They also find that this substitution behaviour has predictive power for bank borrowing and investment of small (out-of-sample) firms, which are not able to issue bonds. In a related paper, Adrian et al. (2012) also document the shift from loans to bonds in the composition of credit in the US, and argue that the impact on real activity comes from the spike in risk premiums, rather than contraction in the total quantity of credit. Gertler (2012) adds, by sketching a simple conceptual framework, that credit spreads are a more useful indicator of credit supply disruptions than credit quantities. Gertler (2012) cites Gilchrist and Zakrajsek (2012), who conclude that the increase in spreads during the recent financial crisis was likely symptomatic of unusual financial distress, and not just the reflection of the increased default risk faced by borrowers. ${ }^{12}$

Certainly, the above-mentioned studies analysed data that was available at the time of writing and therefore their sample periods end between 2009 and 2011. Since then, a number of attempts were made by European governments and the European Central Bank to help restore normal lending and therefore the finding that credit supply was limited up to 2009 or 2011 may not necessarily imply that such limitations exist now as well. However, European banks

\footnotetext{
${ }^{12}$ These authors argue that a credit supply disruption emerges when banks take losses on their loan portfolio, leading to large losses on their equity capital. Tightening of bank credits increases the demand for open market credit by non-financial firms, which, in conjunction with financial frictions, leads to an increase in open market interest rates as well.
} 
still suffer from a large, $€ 400$ billion, capital shortfall according to the OECD (2013); the share of non-performing loans continues to be high; bank share prices are low even after the recent increases; and banks need to meet tight capital, liquidity and leverage requirements, even though some of the Basel III requirements were relaxed in January 2013 (Basel Committee 2013). These factors suggest that credit supply may remain constrained in the EU.

\section{Substitution of bank loans}

While there was notable substitution of bank loans with debt securities in the US, this was not really the case in continental Europe, as Figure 1 indicated for the aggregate of the euro area. ${ }^{13}$ Figure 5 shows the share of loans in debt liabilities of EU countries in 2008 and 2012. The country-specific evidence confirms the main message that the issuance of securities has hardly replaced loans in continental Europe. Note that since we are using balance sheet data, all kinds of loans, and not just loans from domestic banks, are included.

Figure 5. The share of loans in debt liabilities of non-financial corporations in the EU, 2008 and 2012

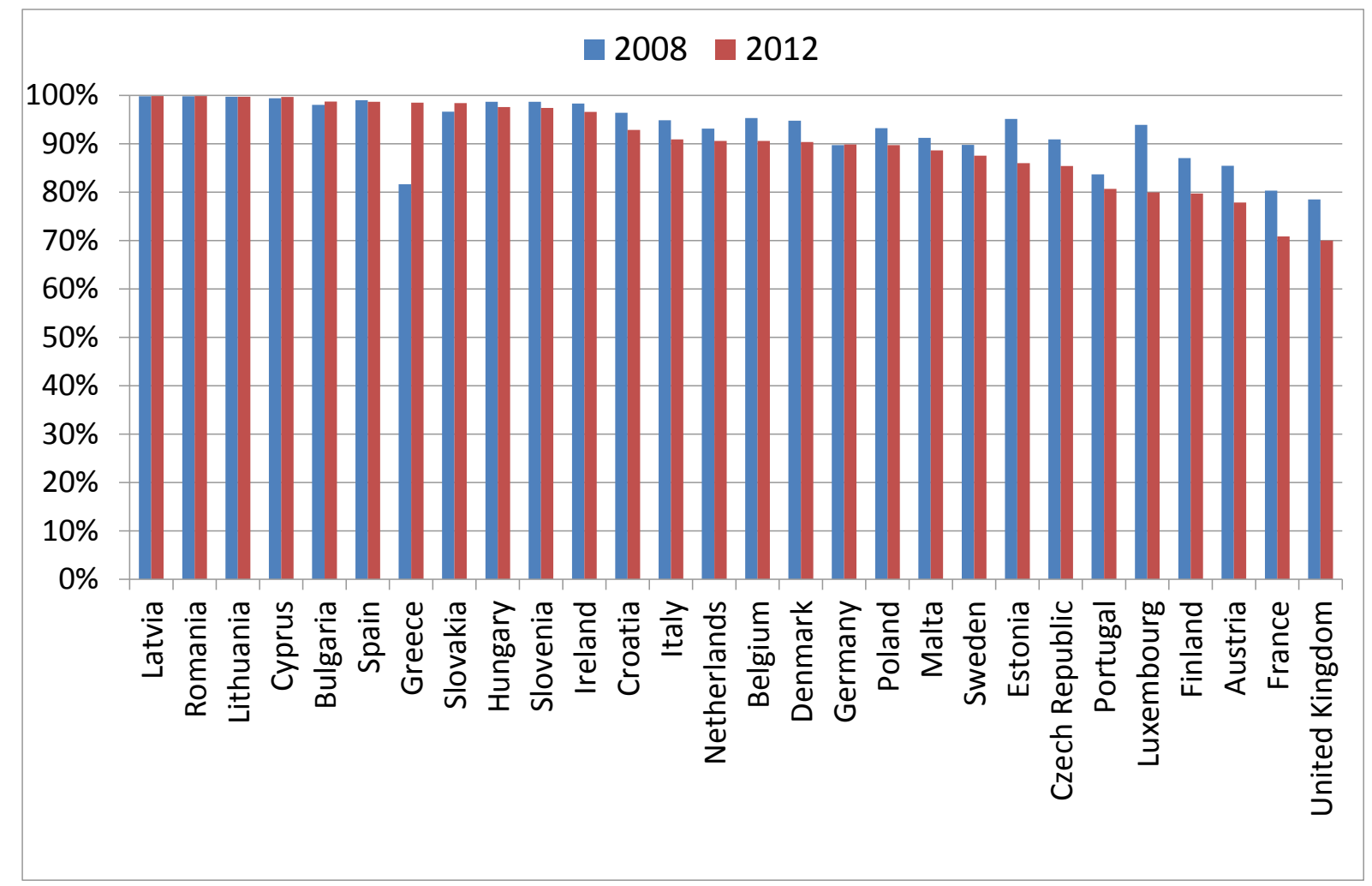

Source: Eurostat 'Financial balance sheets' database.

Note: countries are ordered according to the share of loans in 2012. Consolidated data is used.

Lack of substitution of bank loans with debt securities is a typical problem in bank-based economies, and likely has an implication for the speed of economic recovery. By studying 84 recoveries in 17 OECD countries between 1960 and 2007, Allard and Balvy (2011) found that market-based economies experience significantly and durably stronger rebounds than the bank-based economies. ${ }^{14}$

\footnotetext{
${ }^{13}$ See Bijlsma and Zwart (2013) for a comprehensive account of the mega-trends of financial intermediation in Europe.

${ }^{14}$ However, they also found that stronger recoveries tend to be associated with greater economic flexibility. When employment and product market flexibility are taken into account, the comparative advantage of market-
} 


\section{Concluding remarks}

The literature on creditless recoveries is cautiously optimistic, concluding that while they are not optimal because of weak investment performance, they are not rare and the speed of recovery is still impressive. We also found, by studying historical episodes of economic recoveries in 135 countries during the past five decades, that average yearly real GDP growth during the first three years after the trough was 4.7 percent per year in middle-income countries and 3.2 percent per year in high-income countries. ${ }^{15}$ Many European policymakers would probably be very happy if real GDP growth could reach such rates now.

However, we have drawn a sceptical conclusion on the implications of the historical episodes of creditless recoveries for current European circumstances, for two major reasons.

First, the incidence of creditless recoveries is much lower in high-income countries, which are characterised by high levels of financial development, than in low-income countries in their financial infancy. Since most European countries heavily depend on bank loans, credit constraints could be disruptive. Also, in contrast to the US, where the issuance of debt securities compensated for the withdrawal of bank loans, there has been rather limited substitution in continental Europe.

Furthermore, the issuance of debt securities is not an option for small and medium-sized enterprises (SMEs), which play a crucial role in economic growth and employment. OECD (2012) showed that during the recent credit crunch, SMEs were harder hit than big firms and faced more severe lending conditions. Access to finance thus remains vital for the creation, growth and survival of SMEs. But previous European initiatives were able to support only a tiny fraction of Europe's SMEs; merely stepping-up these programmes is unlikely to result in a break-through. Without repairing bank balance sheets and resuming economic growth, initiatives to help SMEs get access to finance will have limited success. The European Central Bank can foster bank recapitalisation by performing in the toughest possible way the Comprehensive Assessment of banks it has to do before it takes over the single supervisory role. Of the possible initiatives for fostering SME access to finance, a properly designed scheme for targeted central bank lending seems to be the best complement to the banking clean-up, as argued by Darvas (2013).

Second, during historical episodes of creditless recoveries, exchange rate depreciation have likely played a role by increasing revenues from foreign trade, which could have supported company financing when access to credit was limited. We found that while both creditless and with-credit recoveries tend to be associated with real exchange rate depreciation, the depreciation was significantly larger and more persistent during creditless recoveries. In middle-income countries, the median depreciation of the consumer price index-based REER from the pre-crisis peak to three years after the trough was 24 percent, but during with-credit recoveries it was 7 percent. In high-income countries, the same numbers are 10 percent

based economies in recoveries is less significant and therefore it is difficult to claim causality.

${ }^{15}$ These growth rates are high even though they are lower than growth during recoveries with credit. Also, when looking at growth relative to the growth of trading partners, creditless recoveries were less speedy than growth during recoveries with credit, yet still impressive: there was a 1.2 percent extra growth relative to trading partners in middle income countries and a 0.5 percent growth shortfall relative to trading partners in high income countries. 
(creditless) and 2 percent (with-credit).

Since the current global financial and economic crisis erupted, the depreciation in most euroarea countries fell short of these benchmarks. In Ireland, a high-income country, the 15 percent depreciation from pre-crisis peak to 2012 was greater than the benchmark, and the depreciations in Germany ( 9 percent), the Netherlands ( 8 percent), Finland ( 8 percent) and France ( 8 percent) are not far from it. But the depreciations in Italy ( 6 percent), Spain (5 percent), Portugal (5 percent) and Greece (4 percent) are far below the benchmark for the middle-income country group, ie the group to which they belong. ${ }^{16}$ Unfortunately, these southern European countries are also those that experience sizeable contractions in the outstanding stock of bank loans to non-financial corporations and therefore they face the double challenge of limited real exchange rate depreciation and sizeable contraction in credit. $^{17}$

We did not set up a causal model and hence cannot claim that the real exchange rate depreciation was a cause of creditless recoveries, because GDP growth, credit growth and the real exchange rate are endogenous variables. Yet the stylised facts we established suggest that if credit growth does not return, economic recovery may prove to be difficult in the absence of sizeable real exchange rate depreciation.

\section{References}

Abiad, A. - Dell'Ariccia, G. - Li, B. (2011): Credit-less Recoveries. IMF Working Paper $11 / 58$.

Adrian, T. - Colla, P. - Shin, H. S. (2012): Which Financial Frictions? Parsing the Evidence from the Financial Crisis of 2007-9. NBER Working Paper 18335.

Aiyar, S. (2011): How did the crisis in international funding markets affect bank lending? Balance sheet evidence from the United Kingdom. Bank of England Working Paper 424.

Allard, J. - Balvy, R. (2011): Market Phoenixes and banking ducks: Are recoveries faster in market-based economies? IMF Working Paper 11/213.

Basel Committee (2013): Basel Committee releases revised version of Basel III's Liquidity Coverage Ratio', Press Release, Basel Committee on Banking Supervision, 7 January, http://www.bis.org/press/p130107.htm, accessed 3 March 2014.

Bayoumi, T. - Lee, J. - Jayanthi, S. (2006): New Rates from New Weights. IMF Staff Papers 53(2): 272-305.

Becker, B. - Ivashina, V. (2011): Cyclicality of Credit Supply: Firm Level Evidence. NBER Working Paper 17392.

Bernanke, B. - Gertler, M. - Gilchrist, S. (1996): The Financial Accelerator and the Flight to

\footnotetext{
${ }^{16}$ In some of these southern euro-area members, the unit labour cost-based REER index depreciated more than the consumer prices index-based REER, even when controlling for the changing composition of the economy (Darvas 2012b). Unfortunately, the fall in unit labour costs was largely the result of massive lay-offs (Darvas 2012b), and did not translate into a fall in prices, as discussed by Wolff (2012).

${ }^{17}$ In Italy, the real stock of credit to non-financial corporations remained broadly stable until mid-2011, when it started to fall by about 8 percent until end-2012. This cumulative decline is smaller than the declines in Greece, Portugal and Spain and is similar in magnitude to what happened more gradually in Germany between 2008 and 2012.
} 
Quality. Review of Economics and Statistics 78(1): 1-15.

Bijlsma, M. - Zwart, G. T. J. (2013): The changing landscape of financial markets in Europe, the United States and Japan. Bruegel Working Paper 2013/02.

Biggs, M. - Mayer, T. - Pick, A. (2009): Credit and economic recovery. De Nederlandsche Bank Working Paper 218/2009.

Bijsterbosch, M. - Dahlhaus, T. (2011): Determinants of credit-less recoveries. European Central Bank Working Paper 1358.

Braun, M. - Larrain, B. (2005): Finance and the Business Cycle: International, Inter-Industry Evidence. The Journal of Finance 60(3): 1097-1128.

Calvo, G. A. - Izquierdo, A. - Talvi, E. (2006a): Phoenix Miracles in Emerging Markets: Recovering without credit from systemic financial crises. NBER Working Paper 12101.

Calvo, G. A. - Izquierdo, A. - Talvi, E. (2006b): Sudden Stops and Phoenix Miracles in Emerging Markets. American Economic Review 96(2): 405-410.

Claessens, S. - Kose, M. A. - Terrones, M. E. (2009a): A recovery without credit: Possible, but..., 22 May, voxeu.org.

Claessens, S. - Kose, M. A. - Terrones, M. E. (2009b): What happens during recessions, crunches and busts? Economic Policy 24(60): 653-700.

Darvas, Z. (2012a): Real effective exchange rates for 178 countries: a new database. Bruegel Working Paper 2012/06.

Darvas, Z. (2012b): Compositional effects on productivity, labour cost and export adjustment. Bruegel Policy Contribution 2012/11.

Darvas, Z. (2013): Banking system soundness is the key to more SME financing. Bruegel Policy Contribution 2013/10.

Del Giovane, P. - Eramo, G. - Nobili, A. (2012): Disentangling demand and supply in credit developments: A survey-based analysis for Italy. Journal of Banking \& Finance 35: 27192732 .

Gilchrist, S. - Zakrajsek, E. (2012): Credit Spreads and Business Cycle Fluctuations. American Economic Review 102(4): 1692-1720.

Gill, I. - Raiser, M. and others (2012): Golden growth: Restoring the lustre of European economic model. Washington DC: World Bank.

Hempell, H. S. - Kok Sørensen, C. (2010): The impact of supply constraints on bank lending in the euro area: Crisis induced crunching? European Central Bank Working Paper 1262.

Hodrick, R. - Prescott, E. C. (1997): Postwar U.S. Business Cycles: An Empirical Investigation. Journal of Money, Credit, and Banking 29(1): 1-16.

Hristov, N. - Hülsewig, O. - Wollmershäuser, T. (2012): Loan supply shocks during the financial crisis: Evidence for the Euro area. Journal of International Money and Finance 31: 569-592.

International Monetary Fund (2009): World Economic Outlook. Washingotn DC: IMF.

Jimenéz, G. - Ongena, S. - Peydró, J.-L. - Saurina, J. (2012): Credit Supply versus Demand: Bank and Firm Balance-Sheet Channels in Good and Crisis Times. European Banking Center Discussion Paper 2012-003. 
OECD (2012): Financing SMEs and Entrepreneurs 2012: An OECD Scoreboard. Paris: OECD.

OECD (2013): Strengthening Euro Area banks, http://www.oecd.org/eco/economicoutlookanalysisandforecasts/strengtheningeuroareaban ks.htm, accessed 5 March 2014.

Ravn, M. O. - Uhlig, H. (2002): On adjusting the Hodrick-Prescott filter for the frequency of observations. The Review of Economics and Statistics 84(2): 371-375.

Veugelers, R. (2011): Assessing the potential for knowledge-based development in transition countries. Society and Economy 33(3): 475-504.

Wolff, G. B. (2012): Arithmetic is absolute: euro area adjustment. Bruegel Policy Contribution 2012/09. 


\section{APPENDIX 1: DATA SOURCES FOR THE CALCULATIONS IN SECTION 2}

GDP: GDP at constant prices is from the IMF's World Economic Outlook (WEO) October 2012 for 1980-2017 (when available). Missing data and earlier data was chained to the WEO data from IMF International Financial Statistics, World Bank World Development Indicators (WDI), EBRD and the Maddison dataset.

GDP of trading partners: for each country we calculated the weighted average of real GDP growth of trading partners, using country-specific weights derived on the basis of Bayoumi, Lee and Jaewoo (2006). Due to missing data (mostly for transition economies before 1990), we calculated two indices: one using GDP data of 145 countries, which is available form 1960, and another one using GDP data of 175 countries for recoveries in 1993 and later.

GDP per capita at PPP (purchasing power parity) relative to the United States: the main source of GDP per capita at PPP is the October 2012 IMF WEO, which includes data for 1980-2017 with some gaps for some countries. The figures relative to the U.S. were calculated from this database for 1980-2017. Missing values during from 1980, and values before 1980, were approximated by calculating the change in real GDP per capita relative to the US and chaining this ratio to the most recent data available on relative GDP per capita at PPP in the IMF WEO. Real GDP growth rates are from the sources described above, while population data is from World Bank WDI.

Credit: 'Claims on private sector', line 32D, from IMF International Financial Statistics.

Credit/GDP: nominal credit divided by nominal GDP, which is from the IMF World Economic outlook October 2012 and IMF International Financial Statistics.

Real credit: nominal credit deflated by the consumer price index, which is from the IMF International Financial Statistics.

Real effective exchange rate: updated database of Darvas (2012a). Due to missing data, we have calculated the real effective exchange rate against four different country groups: against 172 countries for 1993-2012, against 145 countries for 1980-2012, against 99 countries for 1970-2012 and against 67 countries for 1960-2012. For each case of recovery, we use the broadest available REER.

Exports and Imports (\% GDP): for most countries, data is available in the IMF International Financial Statistics for all three variables (exports of goods and services, imports of goods and services, and GDP; all are at current prices). Missing data for exports and imports were filled from UNCTAD. 


\section{APPENDIX 2: LIST OF CREDITLESS RECOVERIES}

\begin{tabular}{|c|c|c|}
\hline $\begin{array}{l}\text { High income } \\
\text { countries }\end{array}$ & $\begin{array}{l}\text { Middle income } \\
\text { countries }\end{array}$ & Low income countries \\
\hline Norway 1990 & Greece 1987 & Guyana 1990 \\
\hline United States 1991 & Barbados 1973 & Congo, Rep. 1987 \\
\hline Denmark 1975 & Gabon 1987 & Philippines 1985 \\
\hline France 1993 & Portugal 1986 & Ivory Coast 1984 \\
\hline Italy 1993 & Portugal 1975 & Indonesia 1998 \\
\hline Hong Kong 1998 & Mexico 1983 & Sri Lanka 1989 \\
\hline & Trinidad and Tobago & \\
\hline Sweden 1993 & 1984 & Djibouti 1996 \\
\hline United Kingdom 1975 & Jamaica 1976 & Madagascar 1973 \\
\hline Bahamas 1975 & Mexico 1995 & Senegal 1983 \\
\hline Gabon 1978 & Malta 1974 & Ghana 1976 \\
\hline Finland 1993 & Malaysia 1998 & Papua New Guinea 1997 \\
\hline Iceland 1961 & Argentina 1990 & Ivory Coast 1992 \\
\hline & Brazil 1992 & Cameroon 1994 \\
\hline & Argentina 2002 & Papua New Guinea 1990 \\
\hline & Uruguay 1985 & Niger 1969 \\
\hline & Botswana 1994 & Pakistan 1972 \\
\hline & Uruguay 2002 & Nigeria 1987 \\
\hline & Suriname 1993 & Tanzania 1965 \\
\hline & Chile 1983 & Tanzania 1969 \\
\hline & Ecuador 1983 & Sierra Leone 1992 \\
\hline & Colombia 1985 & Tanzania 1974 \\
\hline & Guyana 1973 & Comoros 1991 \\
\hline & Paraguay 1983 & Benin 1989 \\
\hline & & Central African Republic \\
\hline & Colombia 1999 & 1983 \\
\hline & Tonga 1989 & Zambia 1995 \\
\hline & Ecuador 1987 & Guinea Bissau 1998 \\
\hline & Thailand 1998 & Mali 1978 \\
\hline & Ecuador 1999 & Haiti 2004 \\
\hline & Botswana 1977 & Togo 1993 \\
\hline & Paraguay 2002 & Uganda 1980 \\
\hline & Belize 1982 & Tanzania 1994 \\
\hline & Western Samoa 1991 & Malawi 1981 \\
\hline & & Burkina Faso 1990 \\
\hline & & Burundi 1980 \\
\hline & & Sierra Leone 1997 \\
\hline & & Sudan 1985 \\
\hline & & Sudan 1996 \\
\hline & & Malawi 1994 \\
\hline
\end{tabular}

Note: the cases are ordered according to GDP per capita in the year of trough. 